Oyesiku et al., Afr J Tradit Complement Altern Med. (2013) 10(3):144-150

http://dx.doi.org/10.4314/ajtcam.v10i4.23

\title{
MORPHOLOGICAL AND ANATOMICAL INVESTIGATIONS INTO THE MECHANISM OF LEAF PAIR UNROLLING IN URARIA PICTA (JACQ.) DESV. EX DC. (PAPILIONACEAE), A MEDICINAL PLANT IN NIGERIA
}

\author{
Olubukunola O. Oyesiku*, Olubukanla T. Okusanya², James D.Olowokudejo²
}

\author{
${ }^{1}$ Department of Plant Science and Applied Zoology, Olabisi Onabanjo University, Ago-Iwoye \\ Ogun State, Nigeria, ${ }^{2}$ Department of Botany, University of Lagos, Akoka, Lagos State, Nigeria \\ *E-mail: busik1000@yahoo.com
}

\begin{abstract}
Uraria picta leaf-pair unrolling inside out is a remarkable feat. A leaf-pair was investigated to understand the mechanism of spontaneous reverse inside out act of the plant. The upper (adaxial) and lower (abaxial) surfaces of the leaf-pair were examined using scanning and light microscopy. The scan showed diversity of hairs varying in shape from straight, pointed, curve, and club to hook. There were deposits of wax on both sides of the leaf-pair. The light microscope showed hairs are restricted to the midrib on the adaxial surface of the leaflets. Hooked hairs dominated the entire abaxial surface of the leaflets. The transverse section of the midrib section showed abundance of structural and mechanical tissues, collenchyma and sclerenchyma tissues. Both morphological and anatomical attributes were used to explain the mechanism and how the plant got its Yoruba vernacular name 'Alupayida' as well as its purported use in changing the sex of the unborn child and in breaking up love affairs.
\end{abstract}

Keywords: Leaves; Mechanism; Collenchyma; Sclerenchyma; Trichomes; Uraria picta; Wax

\section{Introduction}

The literature is replete with information on Uraria picta (Jacq.) Desv. ex DC. (Waghire et al., 2011; Nair et al., 2006; Ohashi et al., 2006; Anand et al., 1998 ; Okusanya et al.,1992a, b; Okusanya et al.,1991; Okusanya and Olowokudejo 1989; Pradsad et al., 1965 ; Domin 1926). However, local knowledge about Uraria species is decreasing from generation to generation due to increasing destruction of its habitats. U. picta commonly known as wizardry or slight-of-hand herb is very important compared with many other plants (Burkill, 1995). In Nigeria, U. picta is locally known as 'Alupayida' (Yoruba) meaning 'the power of changing object'; 'kaskaifi', 'dakushe', 'wutsiyarbera', 'wutsiyarkusu' (Hausa) meaning 'weapon sharp edge-destroyer'; and 'Obuŏdo dumbwada' (Igbo) meaning 'tail bearer that seeks help to dig the ground'. Chinese traditionalists called U. picta Mei Hua Li Wei Dou (美花狸尾豆) meaning beautiful flower (美花), fox tail (狸尾), bean (豆).

$U$. picta has a long history of use. The purported medicinal and magical uses of this plant had been subjected to analytical argument (Osazuwa et al., 2006; Igboechi et al., 1989; Pradsad et al., 1965). In Nigeria, the leaves of $U$. picta are considered antiseptic and a trace of alkaloid has been detected in the leaves. So, it is used in treating child malaria (Adegoke et al., 1968). Dried leaf powder is an excellent remedy for gonorrhoea and for contractions of the uterus leading to abortion (Anislie, 1937). Alcoholic and aqueous extracts of the woody root contain an active aphrodisiac ingredient reported in Nigeria and Guinea-Bissau (Dalziel, 1937). Lambo (1979) reported that the leaves of $U$. picta prove to reactivate the movement of still foetus in pregnant women and have the power to change the sex of a foetus. Another use recently discovered by the first author is that the application of an ointment prepared from the leaf powder is quite effective in the treatment of goitre.

According to Lambo (1979), in social realm, the red leaved species, $U$. rufescens, though rare, has higher potency than the green-leaved $U$. picta. It is purported to be effective in charms for invisibility and for breaking up friendship and love affairs. Juice from fresh leaves of $U$. picta when rubbed on the body proves to be skin hardener against cut with sword or knife (Lambo 1979).

The greatest interest in $U$. picta lies in the ability of a pair of its leaflets to turn inside out when rolled and beaten together, thus the local Yoruba name 'Alupayida'. The turning ability of the leaflets, which has never been known in any plant in the family or any other plants, has made $U$. picta a unique and unexploited prospective plant for scientific research. Okusanya and Olowokudeju (1989) used the leaf morphology to describe the possible mechanism for the unrolling of the leaf pair but did not study the possible contribution of the anatomical structures. The present paper attempted to scientifically explain the 'beat-and-turn' mechanism of paired leaflets using both the morphological and anatomical structures of the leaves. The experiments attempted to answer the following questions: 1 . Does the 


\section{Oyesiku et al., Afr J Tradit Complement Altern Med. (2013) 10(3):144-150 http://dx.doi.org/10.4314/ajtcam.v10i4.23}

'doctrine of signature' apply to this plant? 2. What is responsible for the turning of the leaf-pairs? 3 . What are the possible reasons for beating the leaf-pairs?

\section{Materials and Methods Plant Distribution and Description}

Uraria is a small genus of the 'Old world' tropics with one endemic species (U. picta) in Nigeria. This plant originated from Tropical America and spread to south and central tropical Africa and Asia, Southeast Asia, north and west Australia with about twenty-six species (Burkill, 1995; Saunders, 1958; Hooker, 1879; Oliver, 1871). U. picta distribution in Nigeria spreads from derived savannah in the southwest to the north Guinea savannah (true savannah), where bush burning stimulates the re-growth of new plants with odd compound leaflets from the basal-woody plants closest to the ground.

$U$. picta (tribe=Hedysarea) is an erect, basal-woody, annual herb of height ranging from 0.5-2 $\mathrm{m}$ with juvenile simple leaves to mature odd-pinnate compound leaves arranged in an increasing odd number order $(1,3,5,7,9,11)$ from one node to the next above it. Lateral veins of leaves looped with margin. Transition from simple to compound leaves is characterised by heteroblastic leaf formation (Njoku, 1956).

The stem and leaves of $U$. picta are equipped with modified fine, short, straight and hooked hairs. Ecologically, the transition from simple 'youth' leaves to 'adult' odd-pinnate compound leaves is associated with availability of nutrients and duration of light intensity, natural habitat and its ability to trap light (Okusanya, et al., 1991; Njoku, 1956). The inflorescence is elongated, spike-like, terminal racemes (30 cm long $\times 2 \mathrm{~cm}$ wide) with small pink flowers. The fruits are small, pearl, grey, articulated pods (3-5 loments) with sub-persistent bract at the base. Seeds are glabrous, greyish or brownish, stony, tiny $(2 \mathrm{~mm}$ long $\times 1 \mathrm{~mm}$ wide) and weigh averagely $0.3 \mathrm{mg}$. The long, wiry tuber-like taproot (ca. $30 \mathrm{~cm}$ long $\times 10 \mathrm{~cm}$ wide) holds the stem firmly in the ground and enhances post-fire re-growth of the plant.

\section{Collection and preparation of material}

Fresh leaves of $U$. picta were collected from home garden of the first author in Ago-Iwoye, Ogun State, Nigeria $\left(6^{\circ} 57^{\prime} 21^{\prime \prime} \mathrm{N}, 3^{\circ} 55^{\prime} 15^{\prime \prime} \mathrm{E}\right)$. A whole leaf tissue was fixed in formalin-acetic-acid-ethanol. Peels from the middle region of the upper (adaxial) and lower (abaxial) surfaces of a leaflet were stained with $1 \%$ aqueous solution of safranin and mounted in glycerin jelly. Scan electron micrographs of both leaflet surfaces were prepared at the Department of Botany, University of Reading, UK. Transverse section of the midrib section from the middle region of the leaflet was stained with $70 \%$ Phloroglucinol $(5 \mathrm{~g}$ in $100 \mathrm{ml}$ ) for 4 minutes and a drop of conc. HCL was added on the section and mounted on slide in glycerin jelly. The transverse section of the mid-rib was drawn under the light microscope at the Department of Biological Sciences, Ondo State University of Science and Technology, Okitipupa.

\section{Unrolling experiment}

Fresh pluck of $U$. picta leaflets of equal length were obtained from the first author's garden. The pair of leaflets was arranged face to face with the smooth waxy upper (adaxial) surface in close contact. The pair of the leaflets was rolled up from either the base or apex, and held in place on left palm of the hand with the middle finger. The palm of the right hand was used to strike the rolled pair while the middle finger was simultaneously withdrawn. The movement of the leaf-pair was observed and photographed in series (Figure 1).

\section{Results}

The lower and upper epidermal surfaces of the leaf showed diversity of hairs (trichomes). Hairs with uniseriate englandular and club shaped were restricted to the region of the midrib in upper surface (adaxial) of the leaf epidermis and the rest of the lamina was coated with wax deposits (Figs $2 a$ and 3), while the entire lower (abaxial) epidermis showed uniformly distributed modified hooked hairs (Figures 2 b, c and 3 ).

Anatomy of the transverse section of the midrib section showed extensive distribution of both collenchyma cells and sclerenchyma (sclereid) cells. Collenchyma tissue composed of elongated cells with irregular outline interspersed with large spaces (lacunar) distributed under the upper epidermis surface. The sclereid almost isodiametric has extremely hard, thick walls. The distribution formed a flask-shaped at the centre of the midrib enveloping the xylem and phloem tissues, the neck projected towards the upper epidermis surface (Fig 3).

On striking the rolled leaf-pair, the outer leaflet instantaneously turned through $360^{\circ}$, subsequently both leaflets gradually unfolded together in a reverse order resulting in an inward to outward pairing. Pictures of the unrolling process of the leaf-pair are shown in Figs 1a-j. In Figs 1g-j, the unfolded leaf-pair showed lag phase (original position of leaf base) and lead phase (displaced position of leaf base). 
Oyesiku et al., Afr J Tradit Complement Altern Med. (2013) 10(3):144-150 http://dx.doi.org/10.4314/ajtcam.v10i4.23

Upp

C
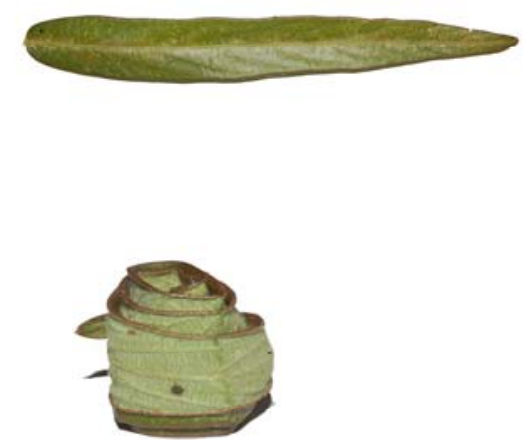

e

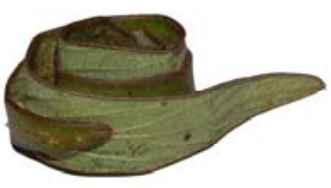

g

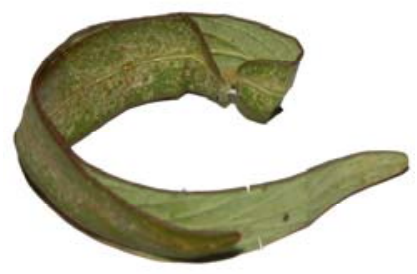

i

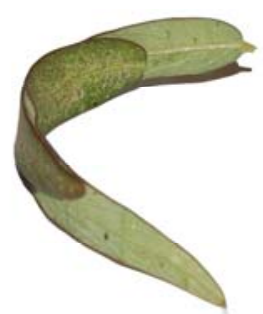

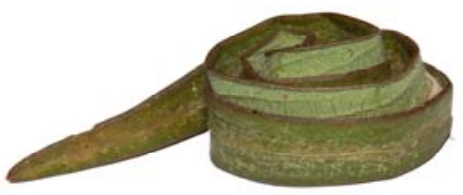

Lo

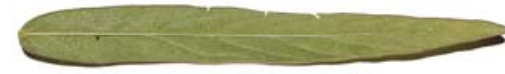

d

f

$\mathrm{h}$

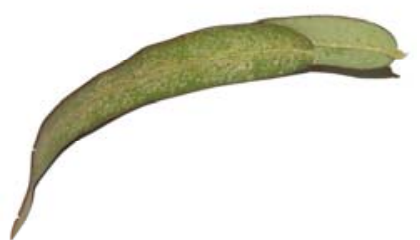

Figures 1: a-j Series of picture captured of turning leaf-pair of $U$. picta.; a = Upper (adaxial) smooth surface of $U$. picta; $\mathrm{b}=$ Lower (abaxial) adhesive surface of $U$. picta; $\mathrm{c}=$ Rolled up pair of leaflets of $U$. picta; $\mathrm{d}=$ Unfolding outer pair of leaflet of $U$. picta; e-f = Unfolding outer and inner pair of leaflet of $U$. picta; $g$-j $=$ Unfolded outer (leading leaflet) and inner (lagging leaflet) of $U$. picta 
Oyesiku et al., Afr J Tradit Complement Altern Med. (2013) 10(3):144-150

http://dx.doi.org/10.4314/ajtcam.v10i4.23
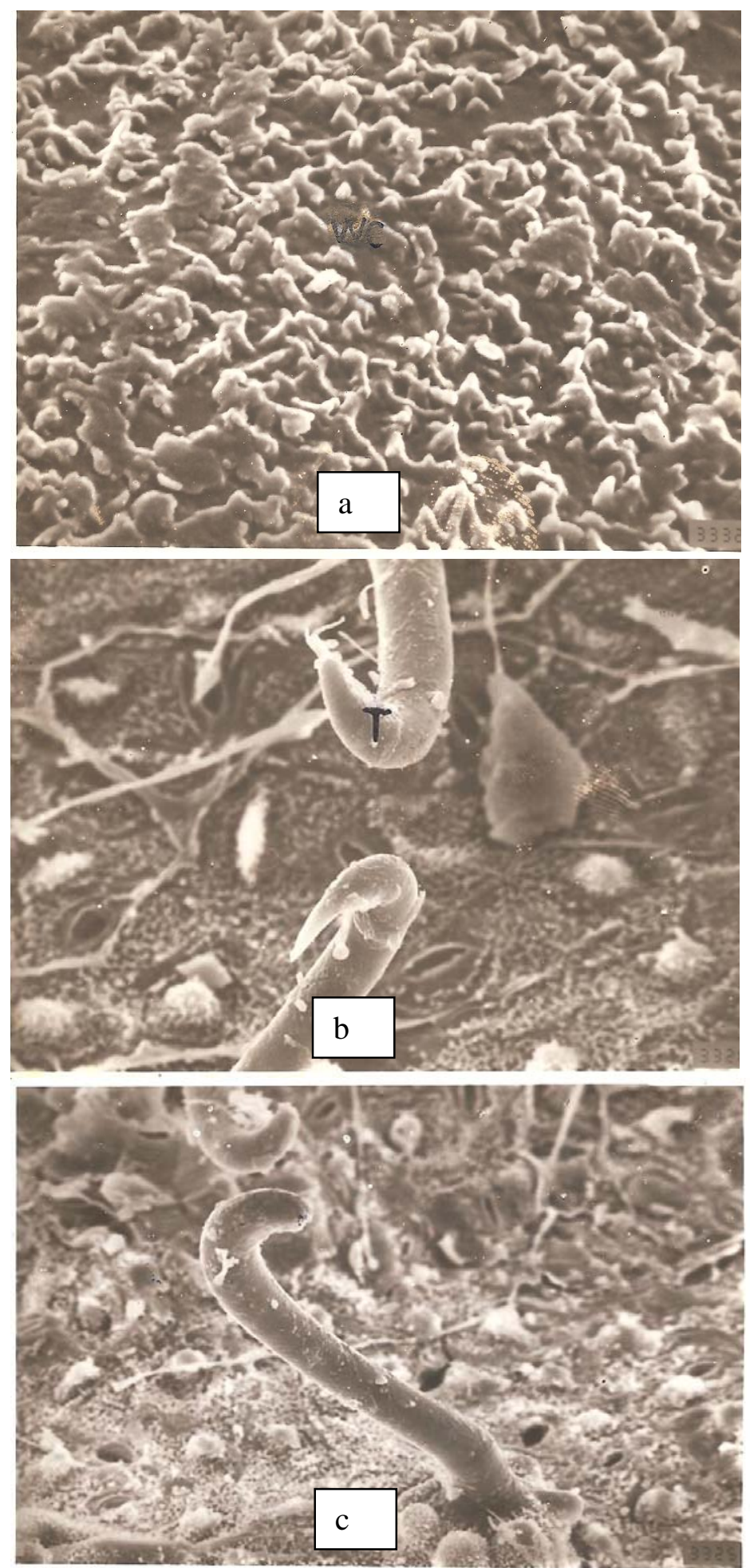

Figure 2: Scan electron micrographs of $U$. picta upper (adaxial) and lower (abaxial) surfaces $a=$ Adaxial surface coated with wax deposits

b, $c$ = Abaxial surface with modified hooked hairs 

http://dx.doi.org/10.4314/ajtcam.v10i4.23

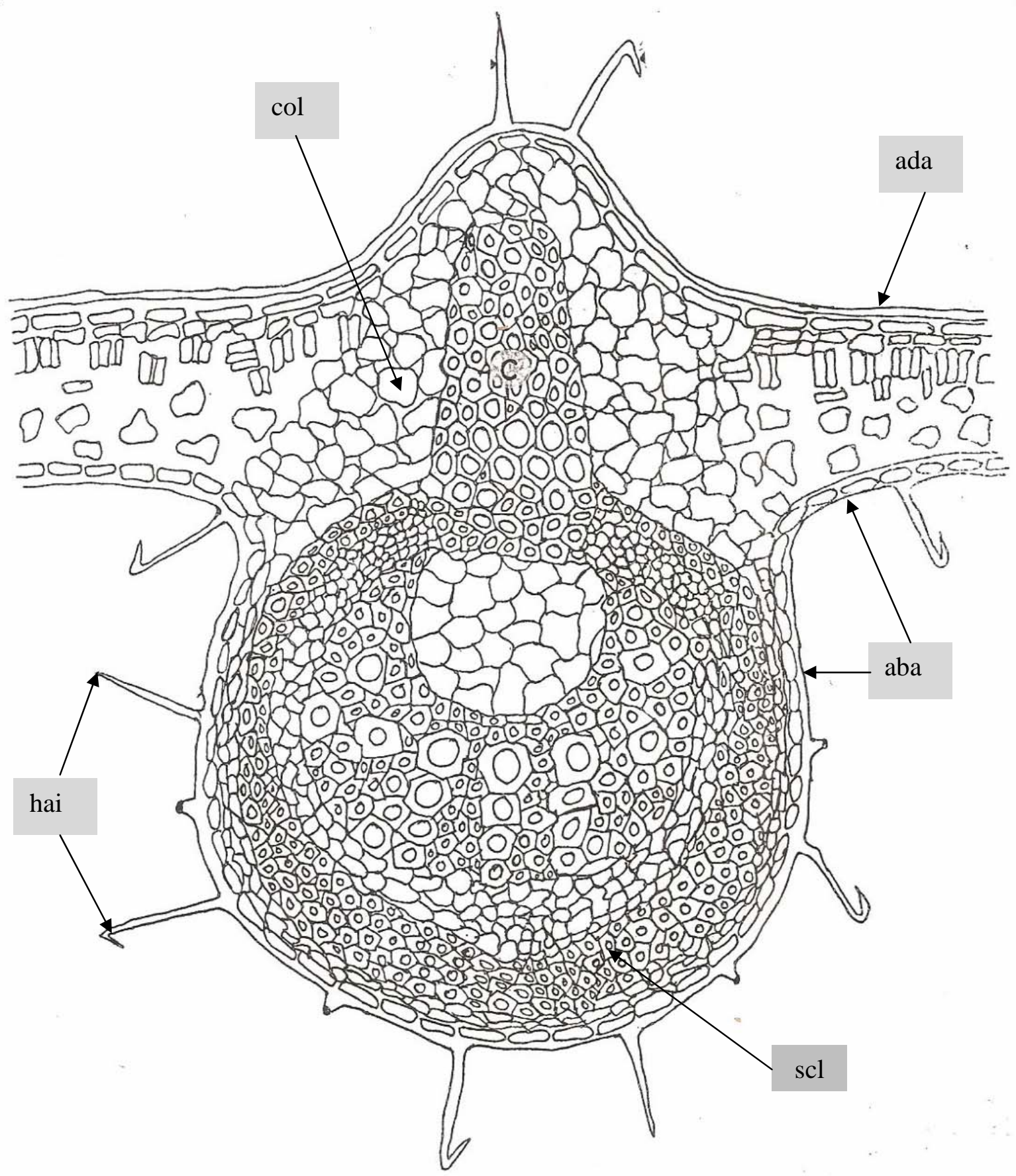

Figure 3: Transverse section of midrib of $U$. picta.

$\mathrm{Ada}=$ Adaxial (upper epidermal) surface; $\mathrm{Aba}=$ Abaxial (lower epidermal) surface; $\mathrm{col}=$ Collenchyma cell scl = Sclereid cell; hai $=$ Hairs $($ Trichomes) 


\section{Oyesiku et al., Afr J Tradit Complement Altern Med. (2013) 10(3):144-150}

http://dx.doi.org/10.4314/ajtcam.v10i4.23

\section{Discussion}

The 'doctrine of signatures' states that the morphological form of a plant gives a clue as to its attitude and healing purposes. Our knowledge of the unique structure of hairs in U. picta comes largely from the works of Kothari and Shah (1975). As reported in their investigation, these authors found more than one hair (trichomes) type in plants they studied. Trichomes in general are uniseriate englandular glandular and club-shaped but hooked forms are peculiar to U. picta. These trichomes play a crucial role in the turning of paired leaflets, thus the 'doctrine of signature' holds for this plant.

Further to the existing information about $U$. picta, it appears that the mechanism of turning inside out of its paired leaflets may be as a result of lamina wax coat and restricted hairs on midribs at the upper surfaces of the leaflets. These surfaces being in close contact enhanced instantaneous elastic repulsion of the contact with the upper smooth surfaces; while one leaflet moved through $360^{\circ}$, the lower adhesive hooked surfaces moved together. Subsequently, the inside of the leaves turned outside. The action was possible given the presence of numerous straight and hooked hairs oriented in various directions. This corroborates the observation of Kothari and Shah (1975).

In addition to Okusanya and Olowokudejo (1989), morphological explanation with the addition of anatomical connotation further supported the uniqueness of $U$. picta in leaf-pair unrolling. The ground tissues, lacunar collenchyma and sclerenchyma sclereids, all provide structural and mechanical support to the leaves of $U$. picta, while they extend and turn. The resilient lacunar collenchyma provides the leaflets with structural support and integrity to withstand several folding and striking. Sclereids, a part of the sclerenchyma tissues, provide the leaflets with flexibility, elasticity and strength, which enhance instantaneous repulsion and quick unfolding of pair of leaflets. The wax deposits not only enhance the slippery movement between the leaflets, they prevent breaking of the leaflets when subjected to frequent rolling up.

\section{Conclusions}

The plant $U$. picta is a unique plant among all other plants, possibly because it retains its 'doctrine of signature'. Its healing and magical powers may still have to be verified. What are responsible for the leaflets turning inside out are the various hooks, wax, lacunar collenchyma and sclereids sclerenchyma. All of these anatomical structures enhance repeated turning of the rolled leaflets. The possible explanation for striking the rolled leaflets was to facilitate adhesion of the lower surfaces in contact and to let the hooks lock. However, without striking, the leaflets could still turn inside out but at a slow rate.

\section{Acknowledgements}

The authors are deeply indebted to late uncle, Mr. Ebenezer Oladele Oyesiku, for introducing us to the plant. We appreciate the suggestions and comments of Prof. A. Egunyomi and Dr Yu NingnNing, the provision of facilities by the University of Reading, UK , State Key Laboratory Institute of Botany, Chinese Academy of Science, Beijing, China and Ondo State University of Science and Technology, Okitipupa, Nigeria.

\section{References}

1. Adegoke, E.A., Akinsanya, A., Naqvi, S.H.Z. (1968). Studies of Nigerian medicinal plants. I. A preliminary survey of plant alkaloids. Journal of West African Science Association. 13: 13-33.

2. Ainslie, J.R. and Imperial Forestry Institute (1937). A list of plants used in native medicine in Nigeria. Oxford: University of Oxford.

3. Anand, A., Srinivasa Rao C., Latha R., Josekutty, P.C., Balakrishna, P. (1998). Micropropagation of Uraria picta, a medicinal plant, through axillary bud culture and callus regeneration. In Vitro. Cellular and Developmental Biology Plant 34: 136-140.

4. Burkill, H.M. 1995). The useful plants of West Tropical Africa $2^{\text {nd }}$ edition vol 3. Royal Botanic Gardens Kew. $p$ 857.

5. Dalziel, J.M. 1937. The useful plants of West Africa $1^{\text {st }}$ edition. Crown Agents for the Colonies, London.

6. Domin, K. (1926). Contributions to the flora and the plant geography of Australia 1. Bibliotheca Bot Heft 89: 741-840.

7. Hooker J.D. (1879). The flora of British India II. L. Reeve \& Co Ltd. London. p 155

8. Igboechi, A.C., Osazuwa, E.O., Igwe, U.E. (1989). Laboratory evaluation of the acaricidal properties of extracts from Uraria picta leguminosae. Journal of Ethno pharmacology 26: 293-298.

9. Kothari, M.J., Shah, G. I. (1975). Epidermal structures and ontogeny of stomata in the Papilionaceae (Tribe Hedysareae). Bot. Gaz. 136 (4): 372-379. 
Oyesiku et al., Afr J Tradit Complement Altern Med. (2013) 10(3):144-150 http://dx.doi.org/10.4314/ajtcam.v10i4.23

10. Lambo, J.O. (1979). The healing power of herbs with special reference to obstetrics and gynecology. Sofowora, A. (Ed). University of Ife Press. Ile-Ife. pp 23-30.

11. Nair, R., Vaghasiya, Y., Chanda, S. (2006). Screening of some medicinal plants of Gujarat for potential antibacterial activity. Indian Journal of Natural Products 22:17-19.

12. Njoku, E. (1956). Studies in the morphogenesis of leaves. XI. The effect of light intensity on leaf shape in Ipomea caerulea. New Phytol. 55: 91-110.

13. Ohashi, H., Iokawa, Y., Phon, P.D. (2006). The genus Uraria (Leguminosae) in China. Journal of Japanese Botany 81: 332-361.

14. Oliver D. (1871). Flora of Tropical Africa. Pp 613. II Leguminosae, London.

15. Okusanya, O.T., Lakanmi, O.O., Oyesiku, O.O. (1991). Germination ecology of the woody herb Uraria picta from southern Nigeria. Journal of Tropical Ecology 7: 139-146.

16. Okusanya, O.T., Oyesiku, O.O., Lakanmi, O.O. (1992a). Quantitative analysis of the effects of some environmental factors on the growth of the medicinal woody herb, Uraria picta. Nigerian Journal of Botany 5 : 63-74.

17. Okusanya, O.T., Oyesiku, O.O., Lakanmi, O.O. (1992b). Seed dormancy in Uraria picta. Nigerian Journal of Botany 5: 209-218.

18. Okusanya, O.T., Olowokudejo, J.D. (1989). Mechanism of leaf-pair unrolling in Uraria picta Desv. a medicinal plant in Nigeria. American Journal of Botany 76: 183-184.

19. Osazuwa, E.O., Igboechi A.C. (2006). Anti-microbial activity of a chemical isolate from the leaves of Uraria picta. Phytotherapy Research 2 (4): 204-206.

20. Pradsad, G.C., Sankaran, P.S., Deshpande, P.J. (1965). Studies on fracture healing by using radioactive P32 and Ca45 under the influence of Uraria picta. Indian J. Med .Res. 53: 645-650.

21. Saunders H.N. (1958). A handbook of West African flowers. Oxford University Press, London. p 124.

22. Waghire H.B., Survase, S.A., Pokle, D.S. (2011). A preliminary study on the germination of Uraria picta (Jacq.)DC. Journal of Ecobiotechnology. 3 (3): 28-30 